\title{
INCLUSION OF CRUDE CORN OIL WITH HIGH ACIDITY IN THE FEED OF LAYING HENS: ANALYSIS OF EGS PRODUCTION AND QUALITY
}

\author{
INCLUSÃO DO ÓLEO BRUTO DE MILHO COM ALTA ACIDEZ NA RAÇÃO DE \\ GALINHAS POEDEIRAS: PRODUÇÃO E QUALIDADE DE OVOS
}

\author{
Brenda Carla LUQUETTI ${ }^{1}$; Sâmela Keila Almeida dos SANTOS ${ }^{2 *}$; Fernanda Heloisa LITZ $^{3}$; \\ Flávia Sousa Gomes CROSARA ${ }^{2}$; Veridiana Aparecida LIMÃ ${ }^{4}$; Patrícia Lopes ANDRADE \\ Evandro de Abreu FERNANDES ${ }^{6}$ \\ 1. Profa. Dra. do Instituto Master de Ensino Presidente Antônio Carlos - IMEPAC, Araguari, Minas Gerais, Brasil; 2. Doutorandas do \\ Programa de Pós-Graduação em Ciências Veterinárias, Universidade Federal de Uberlândia - UFU, Uberlândia, Minas Gerais, Brasil, \\ *samela-zootecnia@hotmail.com; 3. Profa. Dra. da Faculdade Presidente Antônio Carlos, Uberlândia, Minas Gerais, Brasil; 4. Dra. em \\ Ciências Veterinárias, Uberlândia, Minas Gerais, Brasil; 5. Profa. Dra. do Instituto Federal de Educação, Ciência e Tecnologia do \\ Triângulo Mineiro - IFTM, Campus Uberlândia, Minas Gerais, Brasil; 6. Prof. Dr. da Faculdade de Medicina Veterinária da \\ Universidade Federal de Uberlândia - FAMEV-UFU, Uberlândia, Minas Gerais, Brasil
}

\begin{abstract}
The objective of this study was to evaluate egg production and quality after including crude corn oil with high acidity (CCOHA) in the feed of laying hens. The design was completely randomized to three treatments and six replicates each. The sample included 90 hens of the Lohmann LSL lineage, housed in cages; each cage contained five animals and constituted an experimental unit. The evaluated feeds were cornbased feed with degummed soybean oil (CSO), corn-based feed with CCOHA (CC) and sorghum-based feed with CCOHA (SC). At the end of the 28-day cycle, the following productivity parameters were evaluated: egg weight at laying (EWL), laying percentage (LP), feed conversion per dozen eggs (FCDZ) and feed conversion per egg mass (FCEM). The evaluated internal and external quality parameters of the eggs were yolk percentage (YP), yolk index (YI), and yolk $\mathrm{pH}(\mathrm{YpH})$; albumen percentage (AP), albumen index (AI), and albumen $\mathrm{pH}$ $(\mathrm{ApH})$; percentage shell (PS) and shell surface area (SSA); Haugh unit (HU) and egg yolk color (EYC). There were no significant differences in EW, LP, FCDZ, and FCEM between the experimental feeds. Moreover, the use of crude corn oil with high acidity in laying hens rations did not influence the parameters of YP, YI, YpH, AP, AI, ApH, PS, SSA, HU, and EYC.
\end{abstract}

KEYWORDS: Feed conversion. Haugh Unit. Vegetable oils. Yolk color.

\section{INTRODUCTION}

The Brazilian poultry industry produced 39 billion eggs in 2016 , and $99.57 \%$ of this production was used in the domestic market (ABPA, 2017). The high offer of this product is due to the adaptation of the sector to the new practices and technologies of poultry production, and lower cost of egg production to meet the demands of the consumer market. Eggs are considered a wholefood, low-cost protein product (PASCOAL et al., 2008).

One of the most expensive inputs in egg production is feed (FIGUEIREDO JUNIOR et al., 2014; LOWMAN; ASHWELL, 2016), which can reach $70 \%$ or more of the total cost of production (BIASI et al., 2011), with protein and energy representing $85 \%$ of the feed cost (GUNAWARDANA; ROLAND; BRYANT, 2008).

Oils and fats have a high caloric content, particularly those of vegetable origin, and improve the energy balance of the diet by providing calories that are readily available for consumption, thus enhancing nutrient absorption and reducing the speed of food passage (BERTECHINI, 2012).

Because of the high costs of oils, alternative sources that reduce feed costs and do not affect production performance are necessary. The use of by-products generated from industrial processes is a viable alternative, especially crude corn oil with high acidity (CCOHA), generated in the sugarcane industry as a by-product of alcohol production from corn (MARQUES; CUNHA, 2008), particularly during the off-season of sugarcane production. Sugar mills in the off-season of sugarcane in the region of Goiás and Mato Grosso, are producing alcohol from corn and sorghum grain.

There is practically no difference between soybean degummed oil and corn acid oil, and the average composition of the highest concentration fatty acids in these oils is very similar. In soybean oil there is Oleic Acid (C18: 1) 23\%, Linoleic Acid (C18: 2) 53\%, Linolenic Acid (C18: 3) 7.5\% and Palmitic Acid (16: 0) 12\% while the composition 
corn oil is Oleic Acid (C18: 1) 30\%, Linoleic Acid (C18: 2) 53\%, Linolenic Acid (C18: 3) 1.0\% and Palmitic Acid (16: 0) 12\% being acidity of this oil due to the industrial process that is wet.

Acid corn oil on the market is $80.0 \%$ of the cost of soybean oil. In the laying hen feed, soybean and corn oils account for $2.50 \%$, and soybean oil is equivalent to $7.40 \%$ of the final feed cost, while corn acid oil represents $6.00 \%$ of the total final cost of the feed. In the chicken feed, the most consumed feed in the rearing, the oils participate with $3.45 \%$ and that produced with soybean oil equals $8.90 \%$ of the final cost of the feed, while with corn acid oil represents $7.30 \%$ of final feed cost.

CCOHA has an intense yellow color, which increases the degree of safety of its use in the feed of laying hens because the egg yolk color (EYC) and shell color are considered quality parameters by the industrial sector and final consumers. The EYC, although observed after the egg is opened for consumption, is a decisive parameter for the purchase of eggs by consumers (MOURA et al., 2009). Another factor to consider is the use of CCOHA in sorghum-based feeds, which have low levels of carotenoids. For this reason, CCOHA may improve EYC (OLIVEIRA et al., 2017).

Thus, because it does not know the effect of acidity on this corn oil, the objective of this study was to evaluate the effect of CCOHA added to corn and sorghum based feed formulations on the production parameters and egg quality of laying hens.

\section{MATERIAL AND METHODS}

This study was conducted at the Bird Experimentation Farm of the Department of Veterinary Medicine of the Federal University of Uberlândia, in Uberlândia, Minas Gerais state, Brazil. This study was approved by the Animal Research Ethics Committee under Protocol $\mathrm{N}^{\circ}$ 005/17.

The experiments were conducted in a masonry warehouse with metal structure, fibercement roofing, concrete flooring, and screened walls. The warehouse contained several cages with a total capacity of 300 birds. The cages $(50 \times 45 \mathrm{~cm})$ were made of galvanized wire and contained a linear feeder on the front and a Nipple-type water dispenser in the upper region.

Three treatments and six replicates were randomly distributed in a completely randomized design as follows: CSO, corn-based feed with degummed soybean oil (DSO); CC, corn-based feed with CCOHA; and SC, sorghum-based feed with CCOHA.

The feeds were isoenergetic and isonutritive and formulated considering the age of laying hens and the nutritional recommendations of the Lohmann lineage (technical manual). The feds were made with corn or sorghum, in addition to soybean meal, DSO or CCOHA, dicalcium phosphate, limestone, $\mathrm{NaCl}$, vitamin premix, minerals, and additives (Table 1).

The ingredients were subjected to bromatological analysis in the Laboratory of Analysis of Raw Material and Feeds (LAMRAFAMEV) for providing guidance on the formulations. During feed formulation, the energy value of DSO $(8,786 \mathrm{kcal} / \mathrm{kg})$ was used as a reference (ROSTAGNO et al., 2011), and during ingredient mixing for feed production using sorghum or corn, DSO was replaced with CCOHA in the treatments with CCOHA.

Ninety 120-week-old laying hens of the Lohmann LSL lineage were obtained after a forced molt and egg production of approximately $80 \%$. The animals were housed in cages $(50 \times 45 \mathrm{~cm})$, with five birds per cage (animal density of $450 \mathrm{~cm}^{2} /$ bird), and each cage constituted an experimental unit. Water was provided ad libitum and natural/artificial lighting was provided for 17 continuous hours daily.

The experiment was conducted in a 28-day production cycle. The feeds were given at a daily rate of 115 grams per bird per cage and were divided into two meals $(60 \%$ in the morning and $40 \%$ in the afternoon). At the end of the production cycle, productivity parameters were measured and 12 eggs were collected per treatment for analyzing the internal and external quality, one day after collection.

The number of eggs produced intact, cracked, and broken, and the mean egg weight at laying (EWL) in each experimental unit were recorded daily (once at the end of the day). The amount of feed offered and the number of dead birds were also recorded daily. The following productivity parameters were evaluated: mean laying percentage (LP), EWL, feed conversion per dozen eggs (FCDZ), and feed conversion per egg mass (FCEM).

For quality assessment, eggs were identified and weighed individually. After that, eggs were broken on a flat surface and the height and diameter of the yolk and albumen were measured using a digital caliper rule (Zaas Precision) with an accuracy of $0.01 \mathrm{~mm}$. The yolk index (YI) was calculated by the height of the yolk divided by the diameter of the yolk. The albumen index (AI) was 
calculated by the height of the albumen divided by the weight of the egg. The albumen percentage (AP), yolk percentage (YP), percentage shell (PS) relative to egg weight $(\mathrm{EW})$, and shell surface area (SSA) were also determined (MULLER; SCOTT, 1940). Albumen $\mathrm{pH}(\mathrm{ApH})$ and yolk $\mathrm{pH}(\mathrm{YpH})$ were determined using a bench digital $\mathrm{pH}$ meter (Ionlab). Haugh Unit (UH) was calculated using the formula $\mathrm{UH}=100 \times \log \left(\mathrm{H}+7.57-1.7 \times \mathrm{W}^{0.37}\right)$, where $\mathrm{H}$ is albumen height and $\mathrm{W}$ is egg weight.

Table 1. Ingredient's nutritional composition in the experimental diets.

\begin{tabular}{|c|c|c|c|}
\hline Ingredients (\%) & $\mathrm{CSO}^{4}$ & $\mathrm{CC}^{5}$ & $\mathrm{SC}^{6}$ \\
\hline Graun Corn 7.8 & 61.270 & 61.270 & - \\
\hline Sorghum 8.6\% & - & - & 62.180 \\
\hline Soybean meal 46.5\% & 26.090 & 26.090 & 23.470 \\
\hline Calcarium & 8.330 & 8.330 & 9.040 \\
\hline Dicalcium phosphate & 2.010 & 2.010 & 1.830 \\
\hline $\mathrm{DSO}^{1}$ & 1.550 & - & - \\
\hline $\mathrm{CCOHA}^{2}$ & - & 1.550 & 2.590 \\
\hline Common Salt & 0.350 & 0.350 & 0.350 \\
\hline MC-Mix laying ${ }^{3}$ & 0.200 & 0.200 & 0.400 \\
\hline DL- Methionine & 0.201 & 0.201 & 0.140 \\
\hline \multicolumn{4}{|l|}{ Nutritional Levels } \\
\hline Metabolizable Energy(Kcal/kg) & 2740 & 2740 & 2740 \\
\hline Crude protein $(\%)$ & 17.070 & 17.070 & 16.339 \\
\hline Crude Fiber(\%) & 3.660 & 3.660 & 2.775 \\
\hline Calcium(\%) & 3.900 & 3.900 & 3.900 \\
\hline Available Phosphorus(\%) & 0.430 & 0.430 & 0.430 \\
\hline Sodium(\%) & 0.170 & 0.170 & 0.170 \\
\hline Digestible Arginine(\%) & 0.974 & 0.974 & 0.974 \\
\hline Digestible Phenylalanine+Tyrosine(\%) & 1.348 & 1.348 & 1.348 \\
\hline Digestible Glycine+Serine $(\%)$ & 1.370 & 1.370 & 1.370 \\
\hline Digestible Lysine $(\%)$ & 0.727 & 0.727 & 0.727 \\
\hline Digestible Methionine(\%) & 0.432 & 0.432 & 0.432 \\
\hline Digestible Methionine+Cystine(\%) & 0.650 & 0.650 & 0.650 \\
\hline Digestible Threonine(\%) & 0.558 & 0.558 & 0.550 \\
\hline Digestible Tryptophan (\%) & 0.183 & 0.183 & 0.183 \\
\hline
\end{tabular}

EYC was determined in a Chroma Meter CR-400/410 colorimeter (Konica Minolta, Japan) previously calibrated on a white surface using preestablished standards (BIBLE; SINGHA, 1997). The eggs were broken on a flat surface and the measurements were made directly on the surface of intact yolks at three different points. Three color parameters were evaluated: $\mathrm{L}^{*}$ (brightness; $\mathrm{L}^{*}=0$ black; and $\mathrm{L}^{*}=100$ - white); $\mathrm{a}^{*}$ [transition from green $\left(-\mathrm{a}^{*}\right)$ to red $\left.\left(+\mathrm{a}^{*}\right)\right]$; and $\mathrm{b}^{*}$ [transition from blue $\left(-b^{*}\right)$ to yellow $\left(+b^{*}\right)$ ].

The studied variables were subjected to analysis of variance (ANOVA; $<<0.05)$ and the means were compared using Tukey's test and the statistical software SISVAR (FERREIRA, 2011) at a level of significance of $5 \%$.

\section{RESULTS AND DISCUSSION}

The mean values obtained for the variables related to egg production are presented in Table 2. The parameters EWL, LP, FCDZ, and FCEM did not differ significantly $(p>0.05)$ between CSO and $\mathrm{CC}$, indicating that the replacement of DSO with CCOHA in corn-based feeds did not affect these production parameters. These performance parameters found are within the recommended by the lineage, emphasizing that these birds underwent forced molting.

This result is corroborated by other studies. Nogueira et al. (2014) evaluated the inclusion of different levels of palm oil in the feed of laying hens 
and concluded that plant-derived lipid sources did not affect production variables even as Faitarone et al. (2016) studied 33-week-old laying hens of the Lohmann LSL lineage and concluded that the inclusion of canola, soybean, and linseed oil in the feed did not significantly affect production performance, emphasizing that soybean oil can be replaced by other vegetable sources of oil.

Table 2. Egg weight at laying (EWL), laying percentage (LP), feed conversion per dozen eggs (FCDZ) and feed conversion per egg mass (FCEM) of laying hens submitted to diets containing degummed soybean oil or crude corn oil with high acidity

\begin{tabular}{lllll}
\hline TMT $^{\mathbf{1}}$ & EWL $(\mathbf{g})$ & LP\% & FCDZ & FCEM \\
\hline $\mathrm{CSO}^{2}$ & 65.95 & 76.64 & 1.80 & 2.31 \\
$\mathrm{CC}^{3}$ & 64.52 & 77.14 & 1.74 & 2.24 \\
$\mathrm{SC}^{4}$ & 64.54 & 78.92 & 1.70 & 2.20 \\
\hline $\boldsymbol{C V \%}$ & 3.59 & 9.38 & 10.40 & 10.89 \\
$\boldsymbol{P}$-value & 0.08 & 0.22 & 0.16 & 0.31 \\
\hline
\end{tabular}

Means followed by different letters in the line differ by Tukey test $5 \%(\mathrm{p}<0.05) ;{ }^{1} \mathrm{TMT}$ :Treatments. ${ }^{2} \mathrm{CSO}$ : corn-based feed with degummed soybean oil. ${ }^{3} \mathrm{CC}$ : corn-based feed with crude corn oil with high acidity.. ${ }^{4} \mathrm{SC}$ : sorghum-based feed with crude corn oil with high acidity

In our study, $\mathrm{SC}$ and $\mathrm{CC}$ using CCOHA did not significantly affect EWL, LP, FCDZ, and FCEM $(p>0.05)$. The results of SC and CC corroborate those of Moreno et al. (2007), wherein no production losses were observed when substituting corn with sorghum in the diet of laying hens. The amount of CCOHA in these feeds was equal to the amount of DSO in the test feed (CSO), and both SC and $\mathrm{CC}$ were isoenergetic and isonitrogenous, indicating that the nutritional value of these treatments was similar and that DSO and CCOHA had the same energy content.

Egg quality was not significantly different using the tested feeds (Table 3) $(p>0.05)$. In Dekalb laying hens, the inclusion of soybean oil, linseed oil, or sunflower oil did not affect EW and internal quality parameters (OLIVEIRA, 2008), corroborating the results of this study.

Table 3. Eggs quality parameters of laying hens submitted to diets containing degummed soybean oil or crude corn oil with high acidity

\begin{tabular}{|c|c|c|c|c|c|c|c|c|c|c|}
\hline \multirow[b]{2}{*}{$\mathbf{T M T}^{1}$} & \multirow[b]{2}{*}{$\operatorname{EW}(g)^{2}$} & \multirow[b]{2}{*}{$\mathrm{HU}^{9}$} & \multicolumn{3}{|l|}{ Yolk } & \multicolumn{3}{|c|}{ Albumen } & \multicolumn{2}{|l|}{ Shell } \\
\hline & & & $\mathbf{Y P}^{3}$ & $\mathrm{YI}^{4}$ & YрH & $\mathrm{A}^{5}$ & $\mathrm{AI}^{6}$ & АрH & $\mathbf{P S}^{7}$ & SSA $^{8}$ \\
\hline $\mathrm{CSO}^{10}$ & 64.31 & 77.25 & 26.21 & 0.40 & 5.93 & 61.70 & 0,100 & 8.68 & 10.56 & 74.86 \\
\hline $\mathrm{CC}^{11}$ & 64.98 & 77.70 & 26.71 & 0.38 & 5.88 & 62.78 & 0.103 & 8.52 & 10.73 & 73.38 \\
\hline $\mathrm{SC}^{12}$ & 63.52 & 77.10 & 26.52 & 0.39 & 5.96 & 62.93 & 0.108 & 8.38 & 10.33 & 72.86 \\
\hline$C V \%$ & 5.02 & 7.89 & 6.02 & 7.15 & 0.68 & 2.32 & 13.09 & 2.21 & 8.13 & 4.65 \\
\hline P-value & 0.637 & 0.977 & 0.798 & 0.534 & 0.064 & 0.168 & 0.356 & 0.135 & 0.527 & 0.299 \\
\hline
\end{tabular}

Means followed by different letters in the line differ by Tukey test $5 \%(\mathrm{p}<0.05) .{ }^{1}$ TMT: Treatments. ${ }^{2}$ EW: Egg Weight. ${ }^{3}$ YP: Yolk. ${ }^{4}$ YI: Yolk Index. ${ }^{5}$ A: Albumen. ${ }^{6} \mathrm{AI}$ : Albumen Index. ${ }^{7} \mathrm{PS}$ : Percentage Shell. ${ }^{8} \mathrm{SSA}$ : Shell Surface Area. ${ }^{9} \mathrm{HU}$ : Haugh unit. ${ }^{10} \mathrm{CSO}$ : corn-based feed with degummed soybean oil. ${ }^{11} \mathrm{CC}$ : corn-based feed with crude corn oil with high acidity. ${ }^{12} \mathrm{SC}$ : sorghum-based feed with crude corn oil with high acidity.

Mazalli et al. (2004) studied laying hens fed with a diet containing canola oil, sunflower oil, flaxseed oil, fish oil, or a mixture of $50 \%$ flaxseed oil and $50 \%$ fish oil and found that there was no difference in HU, YP, AP, and YI between these variables, demonstrating that these vegetable oils did not affect egg quality parameters, as observed in our study.

There was no significant difference $(\mathrm{p}>0.05)$ between the tested feeds, and the obtained values were within the range considered normal (7.7-9.5) reported by Brake et al. (1997). The HU values did not differ significantly between treatments and the values considered normal (> 72) (USDA, 2000).

The EYC data are shown in Table 4. There was higher brightness $\left(\mathrm{L}^{*}\right)$ in egg yolks from hens fed on corn (CSO and CC) compared to those fed on sorghum (SC) regardless of the type of oil. Some researchers report that the inclusion of oil in the feed improves both the color intensity of the yolk (SCHOLTYSSEK, 1991). 
Table 4. Colorimetric evaluation of hens' egg yolk fed with crude corn oil with high acidity and degummed soybean oil in rations formulated with maize or sorghum

\begin{tabular}{llll}
\hline TMT $^{1}$ & $\mathbf{L}^{*^{5}}$ & $\mathbf{a}^{*^{6}}$ & $\mathbf{b}^{*^{7}}$ \\
\hline CFSO $^{2}$ & $59.36 \pm 2.76 \mathrm{a}$ & $-5.98 \pm 2.21 \mathrm{~b}$ & $32.44 \pm 3.42 \mathrm{a}$ \\
$\mathrm{CFC}^{3}$ & $60.34 \pm 0.37 \mathrm{a}$ & $-5.99 \pm 0.67 \mathrm{~b}$ & $33.23 \pm 1.01 \mathrm{a}$ \\
$\mathrm{SFC}^{4}$ & $56.03 \pm 2.00 \mathrm{~b}$ & $-8.17 \pm 1.54 \mathrm{a}$ & $27.49 \pm 1.66 \mathrm{~b}$ \\
\hline $\boldsymbol{C V \%}$ & 13.24 & 7.56 & 10.98 \\
$\boldsymbol{P}$-value & $<0.001$ & $<0.001$ & $<0.001$ \\
\hline
\end{tabular}

Means followed by different letters in the line differ by Tukey test $5 \%(\mathrm{p}<0.05) .{ }^{\mathrm{I}} \mathrm{TMT}$ :Tratments. ${ }^{2} \mathrm{CFSO}$ : corn-based feed with degummed soybean oil. ${ }^{3} \mathrm{CFC}$ : corn-based feed with crude corn oil with high acidity. ${ }^{4} \mathrm{SFC}$ : sorghum-based feed with crude corn oil with high acidity ${ }^{5} \mathrm{~L}^{*}$ : brightness $\left(\mathrm{L}^{*}=0\right.$ - black; and $\mathrm{L}^{*}=100$ - white). ${ }^{6} \mathrm{a}^{*}$ : Transition from green $\left(-\mathrm{a}^{*}\right)$ to red $\left(+\mathrm{a}^{*}\right)$. ${ }^{7} \mathrm{~b}^{*}$ : transition from blue $\left(-b^{*}\right)$ to yellow $\left(+b^{*}\right)$.

Moreover, the parameter $a^{*}$ in egg yolks from all treatments did not tend to the red color because all values were negative. The intensity of the red-green transition color $\left(\mathrm{a}^{*}\right)$ was lower in treatment SC compared to CSO and CC. The intensity of the blue-yellow transition color $\left(\mathrm{b}^{*}\right)$ was lower in treatment SC compared to $\mathrm{CSO}$ and $\mathrm{CC}$, indicating lower yellow pigmentation of the yolk in the former compared with corn-based feeds (CSO and (C). This result was expected because of the absence of carotenoid pigments in sorghum grains. Nevertheless, the visual appearance of the yolk color was very similar with the corn and soybean oil based control diet, emphasizing that it could have a good market acceptance.

The inclusion of CCOHA in the feed did not improve $\mathrm{EYC}$ in $\mathrm{SC}$, and the intensity of the yellow color was similar to that of CSO and CC. However, the percentage of CCOHA in SC was approximately $2.59 \%$, which is considered small, particularly because sorghum grains have a low carotenoid content. Therefore, in sorghum-based feeds, a pigment source should be used to maintain the yellow color of the yolk, especially in egg production by laying hens. However, it is important to note that egg color is not correlated with its nutritional value (SANDESKI; PONSANO; GARCIA NETO, 2014), although the consumer often associates the intense yellow pigmentation of the yolk with a healthy food (ROSSI et al., 2015).

The results of LP, EWL, and feed conversion indicate that feed used for older laying hens can be produced using sorghum grains as a total replacement of corn without decreasing the nutritional level of the feed. It can also be hypothesized that the metabolizable energy of CCOHA produced during ethanol production is similar to that of DSO. Therefore, despite the high acidity, CCOHA may be considered an energy byproduct capable of replacing DSO considering the energy content.

\section{CONCLUSION}

High acid corn crude oil is a regional product of the grain biofuel industry, so its use in place of soybean oil becomes an economically viable alternative. Although it does not compromise egg quality and production parameters, the oil inclusion in the level tested was not sufficient to achieve the same egg yolk color levels as chickens eggs under corn diets.

RESUMO: Objetivou-se avaliar a inclusão do óleo bruto de milho com alta acidez (OBMAA) em rações de galinhas poedeiras sobre a produção de ovos e sua qualidade interna e externa. O delineamento foi inteiramente casualizado com três tratamentos e seis repetições cada, com 90 galinhas da linhagem Lohmann $\mathrm{LSL}^{\circledR}$, alojadas em número de cinco aves por gaiola, constituindo cada gaiola uma unidade experimental. Os tratamentos foram: rações base milho com óleo degomado de soja (MOS), milho com OBMAA (MOM) e sorgo com OBMAA (SOM). Ao final do ciclo de 28 dias determinou-se os parâmetros de produtividade: peso dos ovos na postura (POP), porcentagem de postura (POS) e conversões alimentares por dúzia (CAD) e por massa de ovos (CAM). Em seguida foram realizadas as análises de qualidade interna e externa dos ovos:

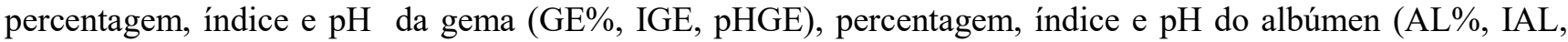
pHAL), percentagem e superfície de área de casca (CAS\%, SACAS), unidade Haugh (UH) e colorimetria da gema. Não houve diferença para POS e POP, CAD e CAM das rações experimentais. A utilização do óleo 
bruto de milho com alta acidez nas rações de galinhas poedeiras não influenciou nos parâmetros de GE\%, IGE, pHGE, AL\%, IAL, pHAL, CAS\%, SACAS, UH e colorimetria da gema.

PALAVRAS-CHAVE: Conversão alimentar. Cor da gema. Óleos vegetais. Unidade Haugh.

\section{REFERENCES}

ABPA 2017 Relatório anual. São Paulo: Associação Brasileira de Proteína Animal, 2017. Disponível em: http://abpa-br.com.br/storage/files/3678c_final_abpa_relatorio_anual_2016_portugues_web_red uzido.pdf. Acesso em: 3 nov. 2017.

BERTECHINI, A. G. Nutrição de Monogástricos. 2. ed. Lavras: UFLA Editora, 2012. 375 p.

BIASI, A.; CIOTTA, D.; MOTTA, M. E. V.; CAMARGO, M. E.; DORION, E. Análise do custo de produção de ovos e a oscilação no preço de venda: uma visão gerencial. Publicações em Medicina Veterinária e Zootecnia, v. 5, n. 15, p. 1093-1099, 2011. http://www.pubvet.com.br/uploads/6467d2d7c 30b 5dc2de6cd74d2591a254.pdf https://doi.org/10.22256/pubvet.v5n15.1093

BIBLE, B. B.; SINGHA, S. Canopy position influences cielab coordinates of peach color. Hortscience, v. 28, n. 10, p. 992-993, 1997. https://doi.org/10.21273/HORTSCI.28.10.992

BRAKE, J.; WALSH, T. J.; BENTON JUNIOR, C. E.; PETITTE, J. N.; MEIJERHOF, R.; PENALVA, P. Egg handling and storage. Poultry Science, v. 76, n. 1, p. 144-151, 1997. https://doi.org/10.1093/ps/76.1.14 4

FAITARONE, A. B. G.; GARCIA, E. A.; ROÇA R. O.; ANDRADE, E. N.; VERCESE, F.; PELÍCIA, K. Yolk color and lipid oxidation of the eggs of commercial white layers fed diets supplemented with vegetable oils. Brazilian Journal of Poultry Science, v. 18, n. 1, p. 009-016, 2016. http://dx.doi.org/10.1590/1516635X1801009-016

FERREIRA, D. F. Sisvar: a computer statistical analysis system. Ciência e Agrotecnologia, v. 35, n. 6, p. 1039-1042, 2011. http://dx.doi.org/10.1590/S1413-70542011000600001

FIGUEIREDO JÚNIOR, J. P; COSTA, F. G. P.; NASCIMENTO, G. A. J.; SANTANA, M. H. M. Aspectos sobre a utilização de aminoácidos totais e digestíveis nas rações para poedeiras. Scientia Agraria Paranaensis, v. 13, n. 3, p. 186-197, 2014. https://doi.org/10.18188/1983-1471/sap.v13n3p186-197

GUNAWARDANA, P.; ROLAND, D. A.; BRYANT, M. M. Effect of energy and protein on performance, egg components, egg solids, egg quality, and profits in molted hy-line w-36 hens. The Journal of Applied Poultry Research, v.17, n.4, p.432-439, 2008. https://doi.org/10.3382/japr.2007-00085

LOWMAN, Z. S.; ASHWELL, C. M. Parental diet effects on egg component weights and shell quality. The Journal of Applied Poultry Research, v. 25, n. 3, p. 437-442, 2016. https://doi.org/10.3382/japr/pfw024

MARQUES, S. J. P.; CUNHA, M. E. T. Produção de álcool combustível utilizando milho. UNOPAR Científica. Ciências Exatas e Tecnológicas, v. 7, n. 1, p. 45-51, 2008.

MAZALLI, M. R.; FARIA, D. E.; SALVADOR, D.; ITO, D. T. A comparison of the feeding value of different sources of fats for laying hens: 1. Performance characteristics. The Journal of Applied Poultry Research, v.13, n.2, p.274-279, 2004. https://doi.org/10.1093/japr/13.2.274

MORENO, J. O.; ESPÍNDOLA, G. E.; SANTOS, M. S. V.; FREITAS, E. R.; GADELHA, A. C.; SILVA, F. M. C. Desempenho e qualidade dos ovos de poedeiras comerciais, alimentadas com dietas contendo sorgo e páprica em substituição alimentadas com dietas contendo sorgo e páprica em substituição ao milho. Acta 
Scientiarum. Animal Sciences, v. 29, n. 2, p. 159-163, 2007. http://dx.doi.org/10.4025/actascianimsci.v29i2 .220

MOURA, A. M. A.; FONSECA, J. B.; MELO, E. A. Lima, V. L. A. G.; Santos, P. A.; Silva, Q. J.

Características sensoriais de ovos de codornas japonesas (Coturnix japônica Temminck e Schlegel, 1849) suplementadas com pigmentantes sintéticos e selenometionina. Ciência e Agrotecnologia, v. 33, n. 6, p. 15941600, 2009. http://dx.doi.org/10.1590/S1413-70542009000600019

MULler, M.; SCOTT, H. M. The porosity of the eggshell in relation to humidity. Poultry Science, v. 19, p. 163-166, 1940. https://doi.org/10.3382/ps.0190163

NOGUEIRA, M. A.; CRUZ, F. G. G.; TANAKA, E. S.; RUFINO, J. P. F.; SANTANA, T. M. Óleo de dendê (Elaeais guineenses Jaquim) na alimentação de poedeiras leves. Revista Acadêmica: Ciência Animal, v. 12, n. 2, p. 103-111, 2014. http://dx.doi.org/10.7213/academica.12.02.AO03

OLIVEIRA, D. D. Fontes de lipídios na dieta de poedeiras: efeito sobre a produção e o perfil de ácidos graxos na gema. 2008. 49 f. Tese (Doutorado em Zootecnia) - Pós-Graduação em Zootecnia, Universidade Federal de Minas, Belo Horizonte, 2008.

OLIVEIRA, M. C.; SILVA, W. D.; OLIVEIRA, H. C.; MOREIRA, E. Q. B.; FERREIRA, L. O.; GOMES, Y. S.; SOUZA JUNIOR, M. A. P. Paprika and/or marigold extracts in diets for laying hens. Revista Brasileira de Saúde e Produção Animal, v. 18, n. 2, p. 293-302, 2017. http://dx.doi.org/10.1590/s1519-

99402017000200008

PASCOAL, L. A. F.; BENTO JUNIOR, F. A.; SANTOS, W. S.; SILVA, R. S., DOURADO, L. R. B.; BEZERRA, A. P. A. Qualidade de ovos comercializados em diferentes estabelecimentos na cidade de Imperatriz-MA. Revista Brasileira de Saúde e Produção Animal, v.9, n.1, p.150-157, 2008.

ROSSI, P.; NUNES, J. K.; RUTZ, F.; ANCIUTI, M. A.; MORAES, P. V. D.; TAKAHASHI, S. E.; BOTTEGA, A. L. B.; DORNELES, J. M. Effect of sweet green pepper on yolk color and performance of laying hens. The Journal of Applied Poultry Research, v.24, n.1, p.10-14, 2015. https://doi.org/10.3382/j apr/pfu003

ROSTAGNO, H. S.; ALBINO L. F. T.; DONZELE J. L.; GOMES, P. C.; OLIVEIRA, R. F.; LOPES, D. C.; FERREIRA, A. S.; BARRETO, S. L. T. Tabelas brasileiras para aves e suínos: composição de alimentos e exigências nutricionais. 3. ed. Viçosa: UFV, 2011.

SANDESKI, L. M.; PONSANO, E. H. G.; GARCIA NETO, M. Optimizing xanthophyll concentrations in diets to obtain well-pigmented yolks. The Journal of Applied Poultry Research, v.23, n.3, p.409-417, 2014. https://doi.org/10.3382/japr.2013-00912

SCHOLTYSSEK, S. Influence of feeding on cholesterol content in eggs. Lohmann information, p. 13-16, 1991.

USDA. Egg-grading manual. Washington: Department of Agriculture, 2000. 56p. Disponível em: https://w ww.ams.usda.gov/sites/default/files/media/Egg\%20Grading\%20Manual.pdf. Acesso em: 5 dez 2017. 